\title{
298sTE BESTUURSVERGADERING.
}

\author{
GEHOUDEN 15 DECEMBER 1888.
}

Tegenwoordig de hh. Kern (Voorzitter), J. H. de Groot (Penningmeester), E. B. Kielstra (Onder-voorzitter), Snouck Hurgronje, Wilken, Niemann, Riedel, de Roo, Humme en Wijnmalen (Secretaris). Afwezig, met kennisgeving, de hl. Martin en Bool.

De notulen van het verhandelde in vorige vergadering worden gelezen en goedgekeurd.

$\mathrm{Na}$ opgave der sedert de vorige bijeenkomst ontvangen boekwerken, welke ter tafel liggen, wordt medegedeeld, dat zijn ingekomen:

10. eene circulaire van het Comité tot regeling van het te Stockholm en Christiania van 2 tot 13 September 1889 te houden Se internationaal Congres der Orientalisten, bevattende mededeelingen betreffende gemeld Congres.

Voor kennisgeving aangenomen, zullende voorts over de deelneming aan het Congres vanwege het Instituut later eene beslissing worden genomen.

2o. missives van de heeren H. P. A. Bakker, te Utrecht, Dr. W. G. C. Byvanck, te Leiden, Jhr. mr. W. Ridder van Rappard, Jhr. mr. W. F. Rochussen te 's Gravenhage, en Dr. J. van der Vliet te Haarlem, - allen houdende bericht, dat zij met $1^{0}$ Januari e. $k$. hun lidmaatschap van het Instituut wenschen neder te leggen.

Voor kennisgeving aangenomen.

3o. eene missive van het lid W. J. Derx, te Nieuwediep, houdende mededeeling van zijn aanstaand vertrek naar Oost-Indië, met verzoek de voor hem bestemde Bijdragen of Werken te willen zenden naar

5e Volgr. IV. 
Zr. Ms. Wachtschip te Batavia, terwijl over de contributie kan beschikt worden aan het adres zijner Echtgenoote, Nieuwediep, 82 Binnenhaven.

Hiervan wordt aanteekening gehouden.

$4^{n}$. missives van de hh. J. A. Kroesen, controleur bij het Binnenlandsch Bestuur in de residentie Oostkust van Sumatra, afd. Batoe Bahra, te Iaboean Roekoe en W. M. H. van Schmid, controleur 1e klasse te Gorontalo, - beide houdende verzoek om als gewone leden van het Instituut te worden opgenomen, laatstgenoemde, zoo mogelijk, met ingang reeds van 10 Januari 1888.

Zonder beraadslaging of hoofdelijke stemming wordt besloten aan het verzoek gevolg te geven en aan Commissarissen te Batavia te zijner tijd mededeeling te doen van de toetreding der beide heeren als gewone leden van het Instituut.

Ten vervolge op zijne mededeeling van 16 November $11 . \mathrm{n}^{0}$. 10388 wordt, onder geleide van een schrịjven van 6 December jl. $1^{\text {e }}$ afd., no. 11040, door den Minister van Buitenlandsche Zaken een afschrift aangeboden eener nadere mededeeling van den ConsulGeneraal der Nederlanden te Kaapstad van 14 November 1l. no. 54, waaruit blijkt, dat men betreffende het verzamelen van bouwstoffen voor een Lapidarium de hulp heeft gevraagd en verkregen, onder anderen, van den heer Leibbrandt, Custodian of Archives, te Kaapstad; de zaak zelve zal echter nog al tijd vorderen, terwijl de kosten vooralsnog onmogelijk kunnen worden opgegeven.

Voor kennisgeving aangenomen.

Van Commissarissen te Batavia zijn ontvangen twee brieven van 11 en 22 October ll. nos. 170 en 171/B., waarbij worden aangeboden twee prima wissels, groot $f 765$ en $f 1224$ N. C., betaalbaar bij de Heeren A. van Hoboken \& Co te Rotterdam, zijnde het bedrag der ontvangen contributiën en subsidiën. De Secretaris deelt mede, dat beide wissels bereids door hem in handen van den Penningmeester zijn gesteld, terwijl de ontvangst daarvan zal worden erkend, met bericht wijders dat inderdaad de heer J. E. Albrecht, laatstelijk in Nederland, voor zijn vertrek naar Indië voor het lidınaatschap heeft bedankt, weswege van hem geene contributie behoeft geïnd te worden.

Onder geleide van een schrijven van 3 December jl. is door den heer M. Nijhoff teruggezonden het geteekende supplement-contract, 
onder dankbetniging aan het Bestuur voor de inwilliging van zijn voorstel, met verzoek voorts het duplicaat, na onderteekening van het Bestuur, te mogen terugontvangen.

Dienovereenkomstig wordt besloten.

Door den heer Nijhoff is mede teruggezonden de hem ter inzage aangeboden rekening van de firma Brill betreffende de uitgave van van Dr. Snouck's Mekka, welke, voor zooverre hij het kan beoordeelen, hem billijk voorkomt. Naar aanleiding eener tot hem gerichte vraag omtrent de wijze van voldoening der rekening, deelt de heer Nijhoff meê, dat, daar de opdracht van het drukken van het werk, enz., door het Bestuur direct aan de firma Brill is geschied, de voldoening der rekening ook door den Penningmeester zal moeten geschieden. In het vervolg, wanneer de bezorging der uitgaven geheel aan den Uitgever wordt overgelaten, zal de verrekening daarvan tegelijk met die van het debiet kunnen plaats hebben. Der firma Brill is voorts reeds bericht, dat enkele posten op de rekening van den Uitgever moeten worden overgebracht, terwijl aan de Redactie van Petermann's Mittheilungen een recensie-exemplaar is gezonden; het Athenaeum en de Academy ontvingen reeds vroeger exemplaren.

Naar aanleiding dezer mededeelingen van des heer Nijhoff bericht de Secretaris, dat de rekening, nadat de verlangde wijzigingen daarin zijn aangebracht, door hem is getoetst en in overeenstemming bevonden met de gedane levering. Wat het aantal exemplaren betreft, volgens vroeger genomen besluit zijn aanvankelijk 500 exemplaren der photographische platen gedrukt, en 800 van den tekst. Uit eene overgelegde nota blijkt, dat van tekst en platen van deel I zijn geleverd 495 exc.; door defecte exemplaren van de platen kan het getal 500 niet geheel worden aangevuld; bij de levering echter der laatste $300 \mathrm{ex}$. van de platen van deel $\mathrm{I}$ zullen er 5 meer bijgeleverd worden om dat te kort te dekken. Wat den tekst van deel I betreft, ten vervolge op de vroegere bezending zijn aan den heer Nijhoff nog 305 exemplaren afgeleverd, makende met de genoemde 495 exemplaren juist de bestelde oplaag van 800 exemplaren.

Met het drukken van het tweede deel is men zeer ver gevorderd; het geheel zal \pm 50 vellen (halve bladen) worden, waarmeê men tegen 't einde van Januari of begin Februari hoopt gereed te zijn. De platen van het tweede deel zijn allen reeds in proef; bij dat deel zullen gevoegd worden 18 photo's, 4 platen in kleurendruk van 
ethnographische voorwerpen, en 1 lithographische plaat. Hoe groot de onkosten van een en ander zullen zijn, kan men voorshands moeielijk nog opgeven.

Met het oog op de aanzienlijke kosten, die de firma Brill reeds bij de levering van het eerste deel heeft moeten bestrijden, geeft de Secretaris aan de vergadering in overweging den Penningmeester te machtigen de hem aangeboden rekening dier firma hetzij geheel, hetzij gedeeltelijk te voldoen.

Dienovereenkomstig wordt besloten.

Nog deelt de Secretaris mede, dat uit het meer aangehaald schrijven van den heer Nijhoff verder blijkt, dat van Niemann's Bloemlezing uit Maleische geschriften, 2e stuk, bij hem nog voorhanden zijn $25 \mathrm{ex}$. Daar het debiet in den laatsten tijd niet is toegenomen, zal een herdruk niet noodig zijn vóór het midden van het jaar 1889. Een oplaag van 1000 exemplaren wordt voldoende geacht.

Gehoord den heer Niemann, wordt, overeenkomstig het voorstel van den Voorzitter besloten, omtrent deze zaak alsnog geene beslissing te nemen, doch haar aan de nadere overweging des heeren Niemann in overleg met den Secretaris aan te bevelen.

De Voorzitter stelt aan de orde de behandeling der begrooting voor het dienstjaar 1889, welke, ingevolge de bepalingen van het Huishoudelijk Reglement, bereids bij al de Bestuursleden in rondlezing is geweest. De Penningmeester licht haar nog nader toe, waarbij tevens eene vraag des heeren Kielstra omtrent het vermoedelijk saldo wordt beantwoord.

In omvraag gebracht, wordt de begrooting met algemeene stemmen aangenomen en mitsdien goedgekeurd, dat zij aan ontvangst aanwijst een bedrag van $f 13,969$, aan uitgaven $f 13.800 .65^{5}$, zoodat er op een vermoedelijk saldo van $f 168.34^{5}$ kan worden gerekend.

Onder toejuiching der vergadering zegt de Voorzitter den Penningmeester dank voor den door hem geleverden arbeid.

Werd door den Voorzitter in eene vorige vergadering de aandacht gevestigd op eene eventueele uitgave van een Sanskrit-tekst, geheel of gedeeltelijk op kosten van het Instituut, thans kan hij mededeelen, dat daarvan voorloopig kan worden afgezien, daar ten gevolge van onderhandelingen met een Amerikaanschen geleerde wellicht de uitgave in Amerika zal plaats hebben. 